University of Nebraska - Lincoln

DigitalCommons@University of Nebraska - Lincoln

Faculty Publications, Department of Child, Youth, and Family Studies

Child, Youth, and Family Studies, Department of

2-13-2013

\title{
Using the Scientific Method to Guide Learning: An Integrated Approach to Early Childhood Curriculum
}

Hope K. Gerde

Rachel E. Schachter

Barbara A. Wasik

Follow this and additional works at: https://digitalcommons.unl.edu/famconfacpub

Part of the Developmental Psychology Commons, Family, Life Course, and Society Commons, Other Psychology Commons, and the Other Sociology Commons

This Article is brought to you for free and open access by the Child, Youth, and Family Studies, Department of at DigitalCommons@University of Nebraska - Lincoln. It has been accepted for inclusion in Faculty Publications, Department of Child, Youth, and Family Studies by an authorized administrator of DigitalCommons@University of Nebraska - Lincoln. 


\title{
Using the Scientific Method to Guide Learning: An Integrated Approach to Early Childhood Curriculum
}

\author{
Hope K. Gerde, Rachel E. Schachter, \\ and Barbara A. Wasik
}

H. K. Gerde (corresponding author), Michigan State University, 552 West Circle Drive, East Lansing, MI 48824, USA email hgerde@msu.edu

R. E. Schachter, School of Education, University of Michigan, 610 E. University Ave., Ann Arbor, MI 48109-1259, USA Current affiliation-University of Nebraska-Lincoln

B. A. Wasik, College of Education, Temple University, 1301 Cecil B. Moore Ave, Philadelphia, PA 19122, USA

\begin{abstract}
Researchers and practitioners have become increasingly interested in how early childhood programs prepare young children for science. Due to a number of factors, including educators' low self-efficacy for teaching science and lack of educational resources, many early childhood classrooms do not offer high-quality science experiences for young children. However, high-quality science education has the potential to lay an important foundation for children's knowledge and interest in science as well as reinforcing and integrating critical language, literacy, and math readiness skills. This paper examines the current research on science in preschool classrooms and provides suggestions on how to teach science that supports children's development across domains. Using the scientific
\end{abstract}

Published in Early Childhood Education Journal 41 (2013), pp 315-323.

DOI 10.1007/s10643-013-0579-4

Copyright (C) 2013 Springer Science+Business Media New York. Used by permission. Published 13 February 2013. 
method to explore science with young children provides a systematic model for engaging children in observation, questioning, predicting, experimenting, summarizing, and sharing results. These processes encourage children's use of language, literacy, and mathematics skills in authentic ways. Suggestions are provided for teachers to use the scientific method as their guide for generating scientific discovery in their classroom.

Keywords: Science, Literacy, Mathematics, Preschool, The scientific method

\section{Introduction}

Science education, especially for young children, has received considerable attention in the past several years. This is perhaps due to the findings that children who engage in scientific exploration in early childhood have a better understanding of science concepts later in life (Eshach and Fried 2005). One of the critical problems facing early childhood science education is supporting teachers to effectively implement science in the classroom. Although the reasons vary, teachers tend not to provide high-quality science experiences in early childhood classrooms (Nayfeld et al. 2011; Tu 2006) and instead teach science through a series of isolated experiments without connection to the broader curriculum. The purpose of this paper is to discuss how the scientific method (which will be described below) can be used in classrooms to effectively help develop science concepts as well as other readiness skills such as language, literacy and mathematics that are critical to young children's development.

First, we will review the research on science in early childhood and illustrate how science education fosters children's language, literacy, and mathematics development. Then, we present each step of the scientific method and explain how each part of the process can support science learning and children's development across domains. In this section, we provide explicit examples of research-based strategies teachers can use to scaffold children's science learning.

Current Science Practice in Early Childhood

Worldwide efforts focused on providing inquiry-based science education in early childhood educational settings have identified 
significant developmental gains for young children (e.g., Howitt et al. 2011; Peterson and French 2008; Inan et al. 2010). Yet opportunities to engage in science, compared to other domain areas, are relatively in early childhood classrooms (Early et al. 2010). Observational work in preschool classrooms considered to be of highquality indicated that opportunities to learn about science were extremely limited (Tu 2006). For example, only half of classrooms had science centers. Even when science centers existed, they offered limited opportunities for science exploration because they provided space for only 1-2 children and, as a result, were rarely used (Nayfeld et al. 2011). Furthermore, during free play, teachers spend less time in science centers as compared to other centers (e.g., dramatic play) thus providing less guidance for children in these areas (Hanley et al. 2009). In general, early educators tend to teach science less often than other domains (Early et al. 2010). Research including classroom observations indicated that preschool teachers mostly engaged in activities unrelated to science $(86.8 \%)$ and rarely engaged in formal (4.5\%) or informal (8.8 \%) science instruction (Tu 2006).

Often, when science instruction is included in the classroom, it is ineffective or presented in a superficial way that only engages children in part of the scientific process (Brenneman et al. 2009). That is, children typically observe and manipulate materials with little guidance from teachers. Specifically, it is not typical practice for early educators to promote children to engage in science processes such as generating questions, making predictions, or hypothesizing (La Paro et al. 2004).

The relatively poor quality of early childhood science may be due to teachers' lack of knowledge in the area of science. Many early educators report limited science content knowledge (Greenfield et al. 2009; Kallery and Psillos, 2001) and recent research has identified preschool teachers to have low self-efficacy with regards to science education (Greenfield et al. 2009). Moreover, early educators in many countries report feeling uncomfortable teaching science to young children (e.g., Conezio and French 2002; Kallery and Psillos 2001). As a result, teachers may provide insufficient or inaccurate explanations for scientific phenomena, sometimes describing occurrences as "magic," rather than providing factual information regarding how or why something happens. 
Early educators should know they are not alone; elementary school teachers also report feeling less prepared and competent to teach science than other content areas (Hamlin and Wisneski 2012; Wenner 1993). Thus, even well-educated teachers may not have the content knowledge for explaining scientific phenomena or may lack skills and confidence for integrating meaningful science experiences into the classroom.

Preschoolers are capable of developing considerable content knowledge about science, although this varies dramatically by child (Greenfield et al. 2009). Thus, young children can understand science concepts when they are presented in developmentally appropriate ways and it is essential to provide accurate science content to young children to expand on their current knowledge of the world and correct misunderstandings (see Duschl et al. 2006 for a review). The field has recognized the importance of science for early childhood through statements from the National Association for the Education of Young Children (2009) and the development of national standards in several countries (e.g., Early Years Learning Framework, Australian Government Department of Education, Employment and Workplace 2009; Head Start Child Outcomes Framework, Office of Head Start 2000). Still, guidance on how to support these expectations is needed. While comprehensive curricula are beginning to strengthen the contributions in science, these materials are lacking in explanations of scientific phenomena, definitions of science terminology, and strategies that integrate science inquiry across the curriculum (e.g., A Head Start on Science, Ritz 2007). Without adequate training and resources, it is not surprising that science activities often are implemented in isolation with little connection to the classroom curriculum or avoided completely (Early et al. 2010; French 2004).

Science Education Integrates Opportunities to Develop Language, Literacy, and Math

Early educators can conceptualize science education as a process of knowledge acquisition (Gelman and Brenneman 2004), rather than the dissemination of facts. Science provides an interesting context in which children develop skills for language, literacy, and math. Further, learning about science helps engage children in 
concept development, a key component of teachers' instructional supports related to children's academic and language skills (Mashburn et al. 2008). Because conceptually linked experiences provide a context for children's learning (Gelman and Brenneman 2004), it is important to provide opportunities for rich conceptual growth that come from scientific exploration, reflection, and question development (Gelman and Lucariello 2002; Winnett et al. 1996). Perhaps most importantly, scientific inquiry provides meaningful opportunities for children to engage in experiences that integrate language, literacy, math, and science education.

Science learning provides a meaningful context to teach children about literacy and to support oral language development. Integrating science experiences into the curriculum can support children's gains in vocabulary development (French 2004) and explanatory language (Peterson and French 2008). In fact, recent research has identified that teachers are more likely to use highquality language (e.g., asking open-ended questions) during science activities than during any other classroom contexts (e.g., dramatic play, math center) (Cabell et al. 2012). This may be because science provides a rich context for engaging in meaningful conversations. Supporting children to learn and use proper scientific terminology as they engage in science exploration helps reinforce new vocabulary, including science equipment/tools (e.g., magnifying glass), natural materials (e.g., pine needle), science processes (e.g., evaporation), and words to describe phenomena (e.g., rough/smooth). As children engage in science experiences, children are encouraged to describe their observations, ask questions, and make predictions-all essential skills which support children's language development longitudinally (e.g., Dickinson and Porche 2011). Encouraging children to record observations and summarize results using science journals supports children to write, use print, and think about letter-sound correspondence within an authentic science experience (Brenneman and Louro 2008).

Scientific inquiry provides opportunities to develop mathematics concepts and skills in a concrete way. As young scientists, children compare, sort, and categorize objects by their properties, which reflects children's ability to represent, analyze, and interpret mathematical data (Epstein 2006). Children can be seen 
counting and using one-to-one correspondence as they engage in observation and experimentation. Further, children can exercise a variety of measurement concepts such as quantity, length, and conservation, which are all fundamental components of children's mathematics development. As children recognize, manipulate, and create their own patterns, they simultaneously begin to understand scientific phenomena and think algebraically (i.e., reasoning about relationships) (Epstein 2003). The charts, diagrams, and graphs that are made during science investigations provide a meaningful and concrete way to discuss concepts of relations, equality, and inequality (Whitin and Whitin 2003).

Because science education has the power to support children's development across domains within a meaningful context, teachers should be empowered to engage in science. The scientific method provides an approachable guide to science because every teacher can encourage children to observe, ask questions, predict, experiment, and discuss their findings, no matter how comfortable they feel with science content. The next section explains how to use the scientific method to teach science and support language, literacy, and math development.

\section{Using the Scientific Method to Teach Thinking Across Domains}

The Scientific Method is a process for asking and answering questions using a specific set of procedures. This process can be used as a guide to create comprehensive and meaningful science experiences for young children. Engaging children in scientific inquiry using all steps of the scientific method supports children to construct conceptually-related knowledge because at each step children use a variety of skills to discover new information about the concept of study (Gelman and Brenneman 2004). The scientific method includes:

- Observing

- Asking questions

- Generating hypotheses and predictions 
- Experimentation or testing of a hypothesis

- Summarizing or analyzing data to draw a conclusion

- Communicating discovery and process to others: verbally and/or in writing

- Identifying a new question

In the following section, we provide a description of each step of the scientific method and ways that teachers can scaffold children's participation in the step. We explain how scientific inquiry supports children's development across domains. The examples illustrate how the scientific method supports science exploration in the science center and in several classroom contexts, including the block area and sand table, at group time, and outdoors. As an illustration, Table 1 provides a brief explanation of the study of worms using the scientific method.

\section{Step 1: Observation}

The first step in the scientific method is observation. This is an opportunity for children to observe the world around them, to find things that intrigue them, and to explore phenomena. Continuous experiences using their senses to explore and describe a variety of materials combined with adult guidance to scaffold this process and develop questions about what they see helps children become better observers (Akman et al. 2003). Defining objects and describing what is being observed, asking questions to guide children's thinking, and supporting children to describe and label what they see supports children to develop new concepts and vocabulary (Copple and Bredekamp 2009; Dickinson and Porche 2011). Including non-fiction texts about a topic of study as classroom resources provides children and teachers with factual information about scientific phenomena (Duke 2007). Also, affording children adequate time to observe and interact with materials is important (Gelman and Lucariello 2002).

For example, during center time, students and teachers can use observation skills to look at and manipulate blocks of various shapes and sizes while talking about whether or not they roll. Supporting children to describe, draw and write their observations 
Table 1. Using the scientific method: a study of worms

\begin{tabular}{|c|c|c|c|}
\hline Scientific method & Description & Example: discovering worms! & Targeted domains \\
\hline Observation & $\begin{array}{l}\text { Opportunity for children to } \\
\text { observe the world around } \\
\text { them, to find things that in- } \\
\text { trigue them, and to start ex- } \\
\text { ploring phenomena } \\
\text { Teachers help children by de- } \\
\text { fining and describing what } \\
\text { is being observed. }\end{array}$ & $\begin{array}{l}\text { Heavy rains last night resulted } \\
\text { in several worms cluster- } \\
\text { ing on the sidewalk. On the } \\
\text { way into school one morn- } \\
\text { ing, children stop to look } \\
\text { at worms on the pavement. } \\
\text { The teacher, Ms. Jenny asks } \\
\text { children what they see and } \\
\text { encourages them to identify } \\
\text { and describe the worms }\end{array}$ & $\begin{array}{l}\text { Scientific skills of observation, } \\
\text { describing, and labeling } \\
\text { Oral language development }\end{array}$ \\
\hline Generating a question & $\begin{array}{l}\text { Based on children's observa- } \\
\text { tions, create a question that } \\
\text { they want to answer } \\
\text { Teachers scaffold children's } \\
\text { language and help them } \\
\text { take their ideas and make } \\
\text { them into questions }\end{array}$ & $\begin{array}{l}\text { As the students walk into the } \\
\text { classroom, one asks, "Do } \\
\text { the worms live on the side- } \\
\text { walk?" another says, "Yeah, } \\
\text { what were they doing } \\
\text { there?" Ms. Jenny says, "I } \\
\text { hear you asking questions. } \\
\text { Maybe this is something we } \\
\text { should investigate. I think } \\
\text { we are asking: why were } \\
\text { the worms on the sidewalk } \\
\text { or above ground after it } \\
\text { rained?" }\end{array}$ & $\begin{array}{l}\text { Scientific skills of generating a } \\
\quad \text { question } \\
\text { Oral language development } \\
\text { Vocabulary knowledge }\end{array}$ \\
\hline $\begin{array}{l}\text { Making predictions and } \\
\text { arriving at a hypothesis }\end{array}$ & $\begin{array}{l}\text { Children use their observations } \\
\text { to make guesses about the } \\
\text { answer to their question } \\
\text { Teachers help children use } \\
\text { what they observed and } \\
\text { background knowledge to } \\
\text { make predictions about the } \\
\text { answer }\end{array}$ & $\begin{array}{l}\text { During circle time, Ms. Jenny } \\
\text { explains that children are } \\
\text { interested in studying } \\
\text { worms. Then she calls on } \\
\text { different students asking } \\
\text { for their hypotheses about } \\
\text { why the worms were above } \\
\text { ground on the sidewalk to- } \\
\text { day. She records children's } \\
\text { predictions on a large piece } \\
\text { of paper }\end{array}$ & $\begin{array}{l}\text { Scientific skills of predicting } \\
\text { and verbalizing ideas } \\
\text { Understanding of print/print } \\
\text { knowledge } \\
\text { Oral language skills }\end{array}$ \\
\hline
\end{tabular}


Table 1. Using the scientific method: a study of worms (continued)

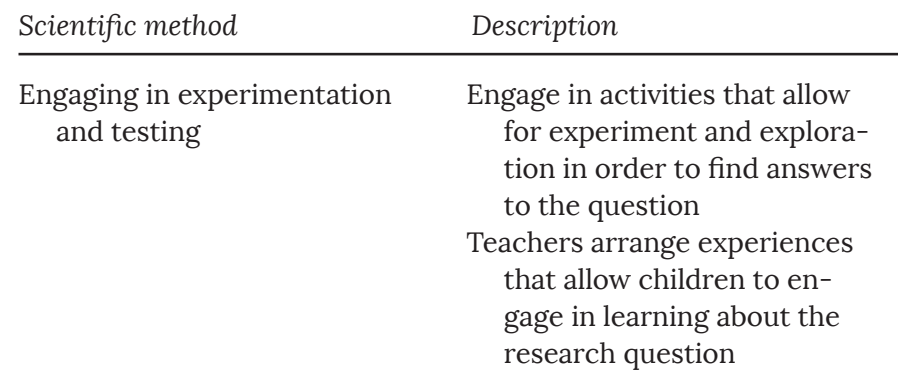

Example: discovering worms!

Ms. Jenny and the children fill a clear plastic tub with dirt and worms and place it in the science center labeled terrarium. She provides paper and markers for students to use to record what they see. Non-fiction books about worms are included in the area. Throughout the course of the study Ms. Jenny and the children introduce different items into the terrarium such as paper and water to watch how the worms respond. Ms. Jenny takes the children on nature walks where they look for worms and talk about when and where they see worms and what the weather is like. When they talk about the weather they make predictions about whether the worms will be in the ground or on the sidewalks. They keep a log of their walks and observations in their science journals. She has students look for worms when they are at home and report to the class what they see
Targeted domains

Scientific skills of observation, charting, recording information

Literacy through writing and recording their observations

Language as they learn and use new vocabulary and report their observations and results to their peers 
Table 1. Using the scientific method: a study of worms (continued)

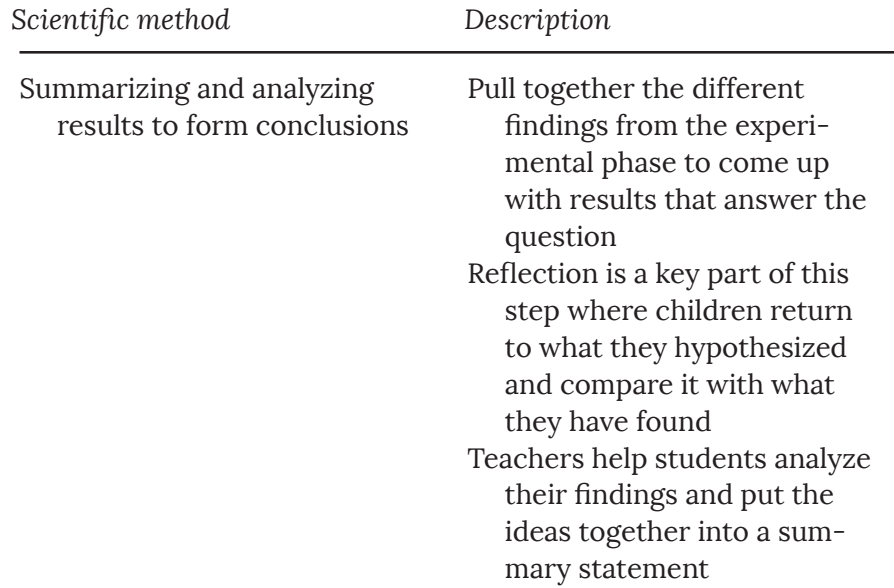

Communicating discoveries

Identifying a new question

Extend children's learning by
Example: discovering worms!

During center time, Ms. Jenny works with small groups of children reading all of the things they have recorded in their science journals. She helps them look for patterns when they saw the worms above ground. They begin to figure out that worms live in the ground but that they move above ground when the ground is very wet (saturated). Next they talk about what they observed the worms doing when they were above ground. Then during circle time, she brings together all of their data and talks through the patterns they found. Putting together all of the evidence that worms come above ground when it is wet, she writes down the class' summary and highlights important concepts and words that they learned about worms

Ms. Jenny has each student draw a picture of what they learned about worms. Then she encourages them to use invented spelling to write some important words or ideas about their findings on their illustration. She helps them by directing them to the group writing example. She binds the worm drawings together into a class book. At group time, each child shares with the class about their page of the class book identifying new questions building from their emerging interests mals that live in the ground.
Targeted domains

Scientific skills of summarizing results and drawing conclusions

Math skills of finding patterns, charting data, and comparing

Oral language is developed as they explain ideas

Science skills of communicating findings

Literacy developing their print knowledge and emergent writing skills
During the course of the study, the children noticed that there might be other aniThey decide to learn more about these animals
Science skills of developing a question and understanding science as a continuous process 
encourages children to notice details of objects, use varied vocabulary, and write (Gerde et al. 2012). Children begin to notice patterns as they identify the physical properties of the blocks (Epstein 2006). Note also, that this observation and exploration is done in the block center and not a designated science center, illustrating that the scientific method can be extended throughout daily activities and areas of the classroom, and should not be confined to the science center ( $\mathrm{Tu} 2006)$.

It is beneficial to provide a wide range of experiences in order to stimulate children's curiosity (Akman et al. 2003; French 2004). For example, depending on the focus of the study and children's interests, introducing a variety of scientific materials (e.g., collections of natural materials, plants, or insects) for children to observe and manipulate offers multiple experiences for engaging in the scientific process of observation. Further, it encourages broadened exploration by providing children opportunities to discover interesting phenomena (e.g., Worth and Grollman 2003). Including science tools with these materials (e.g., magnifying glasses, balance scales) offers children meaningful and scientific ways to engage with these materials. Once introduced, teachers should keep science materials available throughout the classroom, in the science area and throughout the classroom centers (e.g., measuring cups in the dramatic play kitchen, funnels of various sizes in the sand table) (Gelman and Brenneman 2004).

\section{Step 2: Generating a Question}

In order to continue scientific inquiry, a question needs to be asked. The question should come from the children's interests and what they previously observed. Teachers can help students generate testable questions and refine their questions so all children understand. Young children need to develop skills for recognizing and asking questions; asking and responding to questions supports language development (Dickinson and Porche 2011; Wasik and Iannone-Campbell 2012). During the process of generating a question, children not only learn how to ask scientific questions, but that it is acceptable to ask questions and be curious about the world around them. 
Teachers can support children to recognize questions by pointing out when children pose a question (e.g., child: "I wonder why they didn't roll" teacher: "I hear Jalel wonders why some blocks did not roll, he is asking a question about moving or motion"). At circle time, teachers can ask children to describe to their peers the observations they made during free play. Activities that describe observations support children's talking about and understanding of scientific concepts (Gelman et al. 2009). As children describe their observations, teachers can guide question development by summarizing what children observed, and by asking questions to elicit more information from children (e.g., "Do you remember the shape of the block that rolled?"). They can also provide concrete objects to help illustrate children's observations and explanations (e.g., "Why don't you bring the cylinder over to circle so the other boys and girls can see which block is the cylinder?") which can help lead to the formulation of questions.

Writing children's questions on large paper helps to draw children's attention to what they are studying and to the writing process (e.g., "I am going to write that question on our paper because Brittany's question tells me that she is interested in finding out how much it rains when we are at school"). Teachers can ask other children if they have questions about what they have observed about the weather. Teachers can support children's thinking by directing children's attention to the windows to observe and describe the current weather or to the posted graph they created of "September's Weather" where they charted sunny, cloudy, rainy, and snowy days. Using environmental print in meaningful ways supports children to understand that writing has meaning (Clay 2001). Posting the written research questions in the classroom helps children develop print knowledge and can inform families about classroom investigations (Clay 2001).

Step 3: Making predictions and arriving at a hypothesis

During this step of the scientific method, children make hypotheses or predictions about the answer to their question. A body of research literature has shown how making predictions during storybook reading supports young children's language development 
(e.g., Dickinson and Porche 2011). Similar to predicting what will happen during storybook reading, teachers can encourage children to think about what they know about a topic and then guess what they think might be the answer to their scientific question. For example, teachers can ask children to look at the objects and predict whether or not they will roll.

Recording children's hypotheses on large paper and displaying them during the study provides a visual reference for discussions (Gerde et al. 2012). For example, teachers can create a tchart with two columns titled "roll" and "not roll" and blank space along the left side to write the names of the various objects about which children can make predictions. Teachers and children can write the names of the objects as they discuss them. The teacher can encourage the children to write an " $\mathrm{X}$ " in the column corresponding to their hypothesis.

Creating visual representations of data supports children's writing and mathematics skills. Offering children opportunities to explain their thinking to others (e.g., "Why do you think snow melts when you hold it in your hand?") is a crucial component of science that supports cognitive development (Gelman and Brenneman 2004). Further, encouraging children to use the words brainstorm, predict, and hypothesize supports vocabulary development, which is critical for language and science learning (Gelman and Brenneman 2004).

\section{Step 4: Engaging in Experimentation and Testing}

Experimentation or testing occurs when children engage in activities that help them answer their questions. Here teachers engage children in describing, finding patterns, comparing, organizing, measuring, and sorting. Teachers can design activities that guide and scaffold children's experimentation and can follow up on ideas by helping children to think more deeply about those ideas. Experimentation helps to illustrate phenomena in a concrete way, which supports clarification of ideas and concept development (Gelman and Brenneman 2004). Embedding science experiences into the curriculum can support children's understanding of simple experiments and scientific processes (Brenneman et al. 2007). 
Including non-fiction texts in the science area, the book area, and read alouds will support children in using scientific language and will help children understand how to use non-fiction texts to gain information and answer their questions (Duke 2007).

During the experimentation, children should be able to manipulate objects and observe phenomena that exist. It is critical for children to participate in experimentation first hand and not just observe a teacher conduct the test (Gelman and Brenneman 2004) so that they can develop their own understandings of complex scientific phenomena (French 2004). For example, during free play a teacher might show and facilitate the process of experimentation by providing many different objects for children to move. As the children manipulate the different objects, the teacher could verbally explain that as they move a cube block it slides, but as they move a spherical ball it rolls. It is important to provide the materials that children made predictions about earlier and draw children's attention to the chart of predictions so they can intentionally test their hypotheses.

Throughout the study, it is important that many centers include opportunities to experiment with materials related to the research question (Gelman et al. 2009). For example, when studying motion, in art children can paint with objects that roll (e.g., cars, marbles, balls), children can test how object move in sand or water, and can investigate the properties of objects that roll in the block center. Even during outside time teachers and children can engage in observation and experimentation which make connections to what they are doing in the classroom (e.g., "Why do wagons and tricycles roll?"). It is important to leave materials accessible for several days, making sure that everyone has multiple opportunities to experiment with the objects being used in the scientific study (Gelman and Lucariello 2002).

Engaging children in science journaling is a great way to record their own experimentation (Brenneman and Louro 2008). For example, children can record in their journals which objects role by drawing objects into pages labeled 'roll' and 'not roll'. During other experiments children can use their journals to draw and label objects that are living or not living or chart the height of the plants they grow each day for 2 weeks. Children can take these 
journals outdoors to draw and count the frequency of each spring flower they find. Teachers can encourage discussion and reflection of children's discoveries by asking children to share their journal work at group time later (Gerde et al. 2012).

Step 5: Summarizing and Analyzing Results to Form Conclusions

During the summary, teachers help children pull together all of their findings from their experimentation. Teachers scaffold children in representing data visually by listing, charting, graphing, and sorting all of the findings. It is important to assist children in summarizing their findings and/or in making a few general assumptions that answer their initial question. These activities help children to draw conclusions about scientific phenomena and develop concepts (Harlan and Rivkin 2004).

For example, continuing the study of motion, a teacher might bring many objects to circle time and ask children to identify each object and tell her whether the object rolled or not. The activity becomes hands-on, a critical component of early childhood science (Copple and Bredekamp 2009; French 2004) when teachers encourage children to sort the objects into two corresponding piles. To develop summaries teachers ask children to notice similarities or difference between and among the objects (e.g., "Let's look at all these objects that rolled, what is similar or the same about these objects?"). Children should be allowed to provide multiple responses to these summarizing questions. It often helps to record these responses on large paper so they can be repeated as teachers guide children toward a conclusion or an understanding of a concept (Gerde et al. 2012). This is an important time to revise misconceptions children may develop during the experimentation phase (e.g., the child says "It has pointy things;" the teacher responds "Those pointy things are corners. I see several of the objects that do not roll have corners; corners stop an object from rolling.") (Duschl et al. 2006; Gelman and Brenneman 2004; Harlan and Rivkin 2004). After children are finished finding patterns within the two groups of objects, teachers can guide children to reflect on the predictions they made by reviewing their chart. For the first couple of objects, teachers may need to model 
how to respond to the questions (Gelman and Brenneman 2004). After modeling a few responses, the children will begin to explain why some of the objects did or didn't roll. Finally, teachers should ask the original guiding question and summarize children's statements verbally and on the chart.

During a study of the weather, children can use the graphs they have created over several months to analyze weather patterns by summarizing their data. Teachers and children can count the frequencies of each type of weather on each graph and engage in discussions of equality identifying which weather has been observed the most/least for each month. Teachers can guide children to compare the weather of September and December by reflecting on these two graphs. Teachers can draw attention to the words on the graph to support children's accurate summary of patterns in the data.

Step 6: Communicating Discoveries

After making discoveries, it is important for children to have the opportunity to share their findings with others. Communicating about their scientific discoveries supports children's ability to talk about and understand a range of scientific concepts (French 2004; Gelman et al. 2009). Moreover, children are often excited about what they have learned and want to share that information with others. Teachers can help children develop this skill by providing them with different means for sharing their results, such as verbal discussions with others or writing and drawing pictures. The content is science but children use their language and literacy skills to communicate their ideas about science in a meaningful way.

To communicate children's findings, teachers can prepare a one-page newsletter for parents about their study. Integrating writing into this step helps children understand that writing has a communicative purpose (Clay 2001) and provides a meaningful use for technology in the classroom. At circle time, using a laptop (or large paper) a teacher can ask children to help her complete the class newsletter by telling parents what they discovered. She can type (or write) children's words into the newsletter. To prepare children for this activity, the teacher could ask each child 
to pick one object that they experimented with and to explain to a friend why the object did or did not roll, then explain that to the group, and finally to their parents via the newsletter. Teachers can include images of student work (e.g., children's hypothesis chart) in the newsletter as documentation of children's skills (Copple and Bredekamp 2009). This process can be repeated for any scientific study.

Children can also be encouraged to draw their own representations of the findings or to select the charts and graphs they have created during the experiment to explain their conclusions to others. This sharing process supports children's ability to think critically about their study and to use language and literacy skills in a meaningful way, as well as provides relevant and informative communication with parents that was co-constructed by teachers and children.

\section{Step 7: Identifying a New Question}

The final step of the scientific method is to extend the findings from the experiment into a new study. Often in science, one discovery opens the door to new questions. Building upon this $\mathrm{cu}^{-}$ riosity is important because it allows children to follow their interests and use their emerging knowledge to learn more (Worth and Grollman 2003). It also provides a natural way to make connections between themes, something that can often be disjointed in early childhood classrooms (Neuman 2006). Teachers facilitate this process by asking children if they have more questions about what they just learned or by following up on observations that children made during the experimental or summarizing steps. Another method for identifying a new question is for teachers to help children make connections between what they have learned and new contexts. This step begins the cycle of learning again.

For example, at the conclusion of the class study of which objects roll children may become more observant of all objects as they roll. The teacher might encourage the children to notice the speed of different objects on different surfaces (e.g., Teacher, "Wow, the ball goes much slower when it rolls across the mulch. I wonder if it will go faster or slower if we kick it in the gravel or 
the grass"). This may lead children to observing objects roll over various surfaces and introduce a new study of speed. Studies of the weather could lead to studies about the seasons and change, studies about plant growth might lead to investigations of animal growth and child development.

\section{Conclusion}

The scientific method provides early educators with a set of guidelines for exploring science with young children. Through the seven steps of the scientific method, teachers and children engage in activities that allow them to think about scientific concepts, ask questions and participate in a process of discovering answers to questions that children have about the world that they live in. Using the scientific method to guide children's thinking during science activities integrates children's language, literacy, math, and science development. Instead of confining science to the science area, the scientific method promotes the incorporation of science exploration across classroom activities including during group sessions, outdoor time, and in all centers. Through this process, experiences inform and build on one another to enhance learning across developmental domains.

\section{References}

Akman, B., Üstün, E., \& Güler, T. (2003). 6 yaş csedli çocuklarının bilim süreçlerini kullanma yetenek leri [Ability to use science process for children at age 6]. Hacettepe Üniversitesi Eg[vber]-eğitim Fakültesi, Dergisi, 24, 11-14.

Australian Government Department of Education, Employment and Workplace. (2009). Belonging, being, and becoming: The Early Years Learning Framework for Australia. Barton, ACT: Authors.

Brenneman, K., Gelman, R., Massey, C., Roth, Z., Nayfeld, I., \& Downs, L. (2007). Preschool pathways to science: Assessing and fostering scientific reasoning in preschoolers. Santa Fe, NM: Presentation at the biennial meeting of the Cognitive Development Society.

Brenneman, K., \& Louro, I. F. (2008). Science journals in the preschool classroom. Early Childhood Education Journal, 36, 113-119. 
Brenneman, K., Stevenson-Boyd, J., \& Frede, E. (2009). Early mathematics and science: Preschool policy and practice (Preschool Policy Brief No. 19). New Brunswick, NJ: National Institute for Early Education Research.

Cabell, S. Q., DeCoster, J., LoCasale-Crouch, J., Hamre, B. K., \& Pianta, R. C. (2012). Variation in the effectiveness of instructional interactions across preschool classroom settings and learning activities. East Lansing, MI: Paper presented at Michigan State University's Human Development Initiative.

Clay, M. M. (2001). Change over time in children's literacy development. Portsmouth, NH: Heinemann.

Conezio, K., \& French, L. (2002). Science in the preschool classroom: Capitalizing on children's fascination with the everyday world to foster language and literacy development. Young Children, 57(5), 12-18.

Copple, C., \& Bredekamp, S. (2009). Developmentally appropriate practice in early childhood programs serving children from birth through age 8. Washington, DC: National Association for the Education of Young Children.

Dickinson, D. K., \& Porche, M. V. (2011). Relations between language experiences in preschool classrooms and children's kindergarten and fourth-grade language and reading abilities. Child Development, 82, 870-886.

Duke, N. K. (2007). Let's look in a book: Using nonfiction texts for reference with young children. Young Children, 62, 12-16.

Duschl, R. A., Schweingruber, H. A., \& Shouse, A. W. (2006). Taking science to school: Learning and teaching science in grades K-8. Washington, DC: National Academies Press.

Early, D. M., Iruka, I. U., Ritchie, S., Barbarin, O. A., Winn, D. M. C., Crawford, G. M., et al. (2010). How do pre-kindergarteners spend their time? Gender, ethnicity, and income as predictors of experiences in pre-kindergarten classrooms. Early Childhood Research Quarterly, 25, 177-193.

Epstein, A. S. (2003). How planning and reflection develop young children's thinking skills. Young Children, 58(4), 28-36.

Epstein, A. S. (2006). The intentional teacher: Choosing the best strategies for young children's learning. Washington, DC: National Association for the Education of Young Children.

Eshach, H., \& Fried, M. N. (2005). Should science be taught in early childhood? Journal of Science Education and Technology, 14, 315-336.

French, L. (2004). Science at the center of a coherent, integrated early childhood curriculum. Early Childhood Research Quarterly, 19, 138-139.

Gelman, R., \& Brenneman, K. (2004). Relevant pathways for preschool science learning. Early Childhood Research Quarterly, 19, 150-158.

Gelman, R., Brenneman, K., Macdonald, G., \& Roman, M. (2009). Preschool pathways to science (PrePS): Facilitating scientific ways of knowing, thinking, talking, and doing. Baltimore, MD: Paul H. Brookes.

Gelman, R., \& Lucariello, J. (2002). Role of learning in cognitive development. In H. Pashler (Series Ed.) \& R. Gallistel (Vol. Ed.), Stevens' handbook of experimental psychology: Learning, motivation, and emotion (Vol. 3, 3rd ed., pp. 395-443). New York, NY: Wiley. 
Gerde, H. K., Bingham, G. E., \& Wasik, B. A. (2012). Writing in early childhood classrooms: Guidelines for best practice. Early Childhood Education Journal, 40, 351-359.

Greenfield, D. B., Jirout, J., Dominguez, X., Greenberg, A., Maier, M., \& Fuccillo, J. (2009). Science in the preschool classroom: A programmatic research agenda to improve science readiness. Early Education $\mathcal{E}$ Development, 20, 238-264.

Hamlin, M., \& Wisneski, D. B. (2012). Supporting the scientific thinking and inquiry of toddlers and preschoolers through play. Young Children, 67(3), 82-88.

Hanley, G. P., Tiger, J. H., Ingvarsson, E. T., \& Cammilleri, A. P. (2009). Influencing preschoolers' free-play activity preferences: An evaluation of satiation and embedded reinforcement. Journal of Applied Behavior Analysis, 42, 33-41.

Harlan, J. D., \& Rivkin, M. S. (2004). Science experiences for the early childhood years (8th ed.). Upper Saddle River, NJ: Merrill/ Prentice Hall.

Howitt, C., Upson, E., \& Lewis, S. (2011). It's a mystery! A case study of implementing forensic science in preschool as scientific inquiry. Australasian Journal of Early Childhood, 36, 45-55.

Inan, H. Z., Trundle, K. C., \& Kantor, R. (2010). Understanding natural sciences education in a Reggio Emilia-inspired preschool. Journal of Research in Science Teaching, 47, 1186-1208.

Kallery, M., \& Psillos, D. (2001). Pre-school teachers' content knowledge in science: Their understanding of elementary science concepts and of issues raised by children's questions. International Journal of Early Years Education, 9(3), 165-179.

La Paro, K. M., Pianta, R. C., \& Stuhlman, M. (2004). The classroom assessment scoring system: Findings from the prekindergarten year. The Elementary School Journal, 104, 409-426.

Mashburn, A. J., Pianta, R. C., Hamre, B. K., Downer, J. T., Barbarin, O. A., Bryant, D., et al. (2008). Measures of classroom quality in prekindergarten and children's development of academic, language, and social skills. Child Development, 79, 732-749.

National Association for the Education of Young Children. (2009). Standard 2: NAEYC accreditation criteria for curriculum. Retrieved from http://www. naeyc.org/academy/standards/standard2/standard2G.asp

Nayfeld, I., Brenneman, K., \& Gelman, R. (2011). Science in the classroom: Finding a balance between autonomous exploration and teacher-led instruction in preschool settings. Early Education E Development, 22, 970-988.

Neuman, S. B. (2006). The knowledge gap: Implications for early education. In D. K. Dickinson \& S. B. Neuman (Eds.), Handbook of early literacy research (Vol. 2, pp. 29-40).New York, NY: Guilford.

Office of Head Start. (2000). Head start child outcomes framework. Retrieved from http://eclkc.ohs.acf.hhs.gov/hslc/ecdh/eecd/Assessment/Child\%20 Outcomes/edudev art 00090 080905.html 
Peterson, S. M., \& French, L. (2008). Supporting young children's explanations through inquiry science in preschool. Early Childhood Research Quarterly, 23, 395-408.

Ritz, W. C. (2007). A head start on science: Encouraging a sense of wonder. Arlington, VA: National Science Teachers Association Press.

Tu, T. (2006). Preschool science environment: What is available in a preschool classroom? Early Childhood Education Journal, 33, 245-251.

Wasik, B. A., \& Iannone-Campbell, C. (2012). Developing vocabulary through purposeful, strategic conversations. The Reading Teacher, 66(4), 321-332.

Wenner, G. (1993). Relationship between science knowledge levels and beliefs towards science instruction held by preservice elementary teachers. Journal of Science Education and Technology, 2, 461-468.

Whitin, D. J., \&Whitin, P. (2003). Talk counts: Discussing graphs with young children. Teaching Children Mathematics, 10, 142-149.

Winnett, D. A., Rockwell, R. E., Sherwood, E. A., \& Williams, R. A. (1996). Explorations for the early years: Grade pre-kindergarten. Menlo Park, CA: Addison-Wesley.

Worth, K., \& Grollman, S. (2003). Worms, shadows, and whirlpools: Science in the early childhood classroom. Portsmouth, NH: Heinemann. 